\title{
"Evaluating customer perceived value of housing based on location factor and economic value"
}

\begin{tabular}{|c|c|}
\hline \multirow{3}{*}{ AUTHORS } & Elisabet Siahaan (D) https://orcid.org/0000-0003-0806-4618 \\
\hline & Khaira Amalia Fachrudin (D) https://orcid.org/0000-0001-9532-1664 \\
\hline & $\begin{array}{l}\text { Magdalena Linda Leonita Sibarani } \\
\text { Iskandar Muda (D https://orcid.org/0000-0001-6478-9934 }\end{array}$ \\
\hline ARTICLE INFO & $\begin{array}{l}\text { Elisabet Siahaan, Khaira Amalia Fachrudin, Magdalena Linda Leonita Sibarani } \\
\text { and Iskandar Muda (2019). Evaluating customer perceived value of housing } \\
\text { based on location factor and economic value. Problems and Perspectives in } \\
\text { Management, 17(3), 196-206. doi:10.21511/ppm.17(3).2019.16 }\end{array}$ \\
\hline DOI & http://dx.doi.org/10.21511/ppm.17(3).2019.16 \\
\hline RELEASED ON & Wednesday, 21 August 2019 \\
\hline RECEIVED ON & Tuesday, 30 October 2018 \\
\hline \multirow[t]{2}{*}{ ACCEPTED ON } & Thursday, 24 January 2019 \\
\hline & \begin{tabular}{|l|l|l|l|l|} 
EY \\
\end{tabular} \\
\hline LICENSE & $\begin{array}{l}\text { This work is licensed under a Creative Commons Attribution } 4.0 \text { International } \\
\text { License }\end{array}$ \\
\hline JOURNAL & "Problems and Perspectives in Management" \\
\hline ISSN PRINT & $1727-7051$ \\
\hline ISSN ONLINE & $1810-5467$ \\
\hline PUBLISHER & LLC “Consulting Publishing Company "Business Perspectives" \\
\hline FOUNDER & LLC "Consulting Publishing Company "Business Perspectives" \\
\hline
\end{tabular}

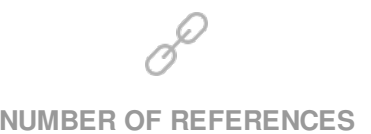

42

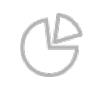

NUMBER OF FIGURES

1

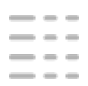

NUMBER OF TABLES

16

(C) The author(s) 2021. This publication is an open access article. 


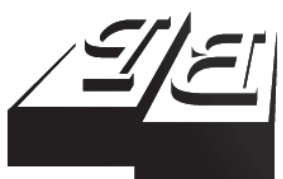

BUSINESS PERSPECTIVES

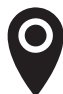

LLC "CPC "Business Perspectives" Hryhorii Skovoroda lane, 10, Sumy, 40022, Ukraine

www.businessperspectives.org

Received on: $30^{\text {th }}$ of October, 2018 Accepted on: $24^{\text {th }}$ of January, 2019

(C) Elisabet Siahaan, Khaira Amalia Fachrudin, Magdalena Linda Leonita Sibarani, Iskandar Muda, 2019

Elisabet Siahaan, Dr., Management Department, Faculty of Economics and Business, Universitas Sumatera Utara, Medan, Indonesia.

Khaira Amalia Fachrudin, Dr., Management Department, Faculty of Economics and Business, Universitas Sumatera Utara, Medan, Indonesia.

Magdalena Linda Leonita Sibarani, Dr., Management Department, Faculty of Economics and Business, Universitas Sumatera Utara, Medan, Indonesia.

Iskandar Muda, Dr., Accounting Department, Faculty of Economics and Business, Universitas Sumatera Utara, Medan, Indonesia.

\section{(ㄷ)(ㄱ)}

This is an Open Access article, distributed under the terms of the Creative Commons Attribution 4.0 International license, which permits unrestricted re-use, distribution, and reproduction in any medium, provided the original work is properly cited.
Elisabet Siahaan (Indonesia), Khaira Amalia Fachrudin (Indonesia),

Magdalena Linda Leonita Sibarani (Indonesia), Iskandar Muda (Indonesia)

\section{EVALUATING CUSTOMER PERCEIVED VALUE OF HOUSING BASED ON LOCATION FACTOR AND ECONOMIC VALUE}

\begin{abstract}
This study seeks to evaluate customer perceived value in housing in order to increase the construction of housing value from the consumer's point of view. A total of 240 houseowners in the middle to upper housings in Medan city, Indonesia, participated in this study. The data analysis used in this study is the Partial Least Square (PLS) approach. The results indicate that the perception of consumer value is strongly influenced by the economic value of the housing and the location function of the housing. Housing offered should be able to meet the needs of consumers and has the good mobility and accessibility. The emphasis that needs to be put in encouraging the perception of consumer value is the ability of the product in general, namely housing units in answering the needs of consumers.
\end{abstract}

Keywords

JEL Classification customer perceived value, partial least square, economic value, location factor, housing value

D13, R21, R31, R53

\section{INTRODUCTION}

Maslow (1943) puts forward the concept of basic needs for human beings, including clothing, food, and boards. The board in the concept is a place to live, a shelter for the weather and the environment. In the concept of need, everyone must have a place to live. In fact, the housing market is not as easy as the theory of residential needs. The theory suggested that everyone will be looking for a place to stay and try to have it. Yet, house is not everyone can easily afford to. Housing or residence is the most expensive component compared to other basic needs. Large investments are needed to generate housing or buy housing. In other words, not everyone is willing to buy housing offered by the developer. Studies conducted by Zrobek et al. (2015) indicate that there are personal influences such as preference in a person's decision to choose to buy a house. Preferences of someone will be different from other people. In these conditions it will be difficult for developers to produce housing in accordance with the preferences of everyone. In marketing a property and housing, it needs to raise the demand for housing itself. The demand relates to a person's preference for the product being offered (Siahaan, 2015). The ability of marketers in creating demand must be able to penetrate the prospective buyer's perception of the product offered. Value concept plays an important role in marketing and demand creation (Kotler \& Keller, 2012). Residential products that have a large cost must be able to create a perception of benefits far greater than the cost to be incurred by those consumers. Appraisal Institute (2008) agrees on a commonly used tag-line element "location, location, and location" to help provide an assessment of reasonable 
property values. In this case, the location factor is one of the important consideration factors in building the perception of consumer value. Srour et al. (2002) in their study state that the value of the house and the value of the location of a residential are evaluated separately. In this case, location is a factor that gives its own value apart from the offered housing units. Kolbe et al. (2012) use the location as a reference assessment of the value of a site based on the rating geographical conditions of the site. HuderekGlapska and Trojanek (2013) and Zemke et al. (2018) evaluate aspects of using the criteria of accessibility and transportation that meet the needs of households, businesses, and other aspects as a basic reference in assessing the location factor accompanied by noise pollution. This indicates that the location has an important role in the value of a home. In addition, the economic concept is known as the economic value of a product, which is a function of DUST (Desire, Utility, Scarcity and Transferable) in determining the value of a product, including housing.

\section{LITERATURE STUDY}

\subsection{Value and perceived value}

Utilization of the concept of customer perceived value today is increasingly and widely used by companies, particularly within the scope of sustained business. This concept is also considered as one of the key factors in achieving business success, reaching and retaining customers, in an era of increasingly fierce competition (Aulia et al., 2016; Lin, 2018; Sirdeshmukh et al., 2018; Erkmen et al., 2018). Sanchez-Fernandez and Iniesta-Bonillo (2007) proposed a multi-dimensional measurement for perceived value. The main key of this concept is the cost-benefit. The cost reflected all of buyers' sacrifice to acquire the product, while the benefit reflected its ability or function to satisfy the needs (Lima et al., 2009; Ashraf et al., 2018; Bakar et al., 2018; Chekalina et al., 2018; Gordon et al., 2018; Gong \& Yi, 2018; Simon \& Tossan, 2018). When consumers feel the benefits gained outweigh the costs, customer satisfaction will be achieved and provide a positive value for the company's products. Aulia et al. (2016) measured customer perceived value via three dimensions (see below).

\subsubsection{Product-related value}

Products are goods or services that consumers use to meet their needs. The two needs are based on the value of experience, convenience, sacrifice, benefits, along with the ergonomics of the product (Creusen \& Schoormans, 2005; Wang et al., 2004, 2018).

\subsubsection{Social-related value}

This dimension describes the benefits from the standpoint of social value obtained on the consumption made. Gallarza and Gil (2006) suggested social acceptance as perceived value in the basic needs theory. This value is based on the need for acceptance in social groups and the need for appreciation, which is derived from the concept of needs by Maslow (1943). The values were perceived based on social environment (Harris et al., 2005).

\subsubsection{Personal-related value}

Every individual has a preference value respectively (Huber et al., 2001; Leckie et al., 2018; Carlson et al., 2018). This value is unique in building their character and decisions. This value is measured based on the need to be yourself and do what is thought to be right. A value can be reflected by each individual's personal taste (Khalifa, 2004).

\subsection{Value concept in housing properties}

The supply point of view is formed by the scarcity and benefits of the housing itself. The combination of supply and demand forms the value of housing. Therefore, the value in this context is a function of desire, benefits, scarcity, as well as purchasing power (Oloke et al., 2013).

\subsection{Factors that affect perception of value}

Ge and Du (2007) argue that the essence of the value of a housing in the property market is determined by various factors. These factors, among 
others, are the age of the building, location, area, the characteristics of the environment, economic activities, transport, population, etc. (Joslin, 2005). Of the various concepts, two of the most instrumental factors in the assessment of a consumer's perspective are summarized in two concepts, namely the economic value and location (Willmore, 2011; Birinci et al., 2018; Dedeoglu et al., 2018; Lee \& Phau, 2018; Hwang et al., 2019).

\subsection{Location}

Kotler and Keller (2012) state that the location is one of the forms of the marketing mix, place, where the choice of product marketing is made. In the context of the value of a housing, Appraisal Institute (2008) defined location as a function of $3 \mathrm{~L}$, 'location, location and location'. The first location is referred to easiness to access the given location. The second one refers to mobility aspect and the last one to public facilities. Willmore (2011) believes that location is a very important factor in shaping the value of a housing in the minds of consumers. In the $3 \mathrm{~L}$ function, the location has three approaches.

\subsubsection{Accessibility}

The location in this case relates to the proximity of the residential location with the access to the main highway.

\subsubsection{Mobility}

The location in this case relates to the proximity between the location of daily necessities housing, e.g. workplace, children's school, market, etc.

\subsubsection{Amenities}

Location in this case relates to the proximity between locations with public facilities such as hospitals, terminals, and so forth. Lundgren (2013) added location elements of the surrounding environment as an important aspect of location assessment, particularly from the point of view of consumers (residency). Anderson et al. (2010) suggested the element of environment in addition to 3L while assessing the locational aspect. It is important to evaluate the locational aspect. Previous study indicated that different location held a different value to others (Kolbe et al., 2013; Wojnarwsky et al., 2017).

\subsection{Economic value}

The concept of value is a different concept with the price. Values are constructs with multiple points of view and no single conception refers to a value (Sweeney, 1994). Economic value is an agreement between buyer and buyer, beyond the market equilibrium price (Willmore, 2011). Betts (2012) stated that real estate such as residential, has no intrinsic value. The value itself was derived from right and benefit. Betts also stated that economic value of housing is the development of the concept of the DUST (Desire, Utility, Scarcity, and Transferable) function. The function can be seen in the demand (desire, transferable) and supply (utility, scarcity) side.

\section{METHODS}

\subsection{Research design}

The nature of this study was explanatory research. Sekaran (2003) suggested explanatory research to evaluate and explain the logical relationship between variables. The study employed a mixture of qualitative and quantitative approaches. The perceptions were converted to each of their numerical value to be analyzed furthermore.

\subsection{Operational definition}

Table 1 summarizes the operational definition of research variables.

Table 1. Operational variables

\begin{tabular}{|c|c|c|c|}
\hline Var & Definition & Dimension & $\begin{array}{c}\text { Measurement } \\
\text { scale }\end{array}$ \\
\hline \multirow{4}{*}{ 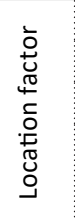 } & \multirow{4}{*}{$\begin{array}{l}\text { The concept of a } \\
\text { housing assessment } \\
\text { based on the location } \\
\text { of the housing is } \\
\text { combined with various } \\
\text { consumer purposes }\end{array}$} & Accessibility & \multirow{4}{*}{ Likert } \\
\hline & & Mobility & \\
\hline & & Facility & \\
\hline & & Environment & \\
\hline \multirow{4}{*}{ 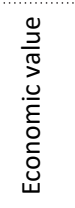 } & \multirow{4}{*}{$\begin{array}{l}\text { The concept of } \\
\text { assessment of a } \\
\text { housing based on the } \\
\text { economic value owned } \\
\text { by the housing }\end{array}$} & Desire & \multirow{4}{*}{ Likert } \\
\hline & & Utility & \\
\hline & & Scarcity & \\
\hline & & Transferable & \\
\hline \multirow{3}{*}{ 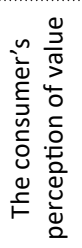 } & \multirow{3}{*}{$\begin{array}{l}\text { The key to success } \\
\text { developer to create } \\
\text { satisfaction based on a } \\
\text { comparison between } \\
\text { the acquisition of } \\
\text { consumers at the } \\
\text { expense of issuance }\end{array}$} & $\begin{array}{l}\text { Product- } \\
\text { related value }\end{array}$ & \multirow{3}{*}{ Likert } \\
\hline & & $\begin{array}{l}\text { Social- } \\
\text { related value }\end{array}$ & \\
\hline & & $\begin{array}{l}\text { Personal- } \\
\text { related value }\end{array}$ & \\
\hline
\end{tabular}




\subsection{Sample and data collection}

There were numerous upper-middle class residential in Medan, North Sumatera, Indonesia. This study asked permission to conduct study to the developers. As the permission granted, the study was conducted at Citra Garden, Citra Wisata, White House Garden, Tasbih Housing (I \& II), Royal Monaco, Gatsu Indah, Asoka Raya Regency and Johor Regency, Medan, Indonesia. A data pool was created based on developers data. The sample was taken randomly based on the pooled data. The selection of random samples can be done in the ongoing process, when the population of the sample frame is not yet available. By using random samples, selected samples tend to be more widespread in the entire population. Therefore, the sample is considered more representative of the population. A number of 240 samples participated in this study. Inferential statistical analysis was used to answer the research hypotheses by using Partial Least Square method using SmartPLS 3.0 (Ringle et al., 2017). The advantage of using SmartPLS is the ability to process data for both formative and reflective SEM models. Formative SEM models have characteristics including latent variables or constructs constructed by indicator variables where the arrow leads from the construct variable to the indicator variable. Reflective SEM model is an SEM model where the construct variable is a reflection of the indicator variable so that the arrow leads from the indicator variable to the latent variable. Statistically, the consequence is that there will be no error value in the indicator variable.

\section{RESULT AND DISCUSSION}

\subsection{Result}

\subsubsection{Instrument reliability}

Reliability test was done in Bumi Miraj Permai housing. Instrument reliability was measured using Cronbach's Alpha. The instrument reliability test results are summarized in Table 2.
Table 2. Reliability analysis

Source: SmartPLS result (2018)

\begin{tabular}{l|c|c}
\hline \multicolumn{1}{c|}{ Variable } & \multicolumn{1}{c}{$\begin{array}{c}\text { Number } \\
\text { of indicators }\end{array}$} & $\begin{array}{c}\text { Cronbach's } \\
\text { alpha }\end{array}$ \\
\hline $\begin{array}{l}\text { Customer perceived } \\
\text { value }\end{array}$ & 14 & 0.873 \\
\hdashline Economic value & 12 & 0.881 \\
\hline \begin{tabular}{l} 
Location factor \\
\hline
\end{tabular} & 12 & 0.902 \\
\hline
\end{tabular}

Table 2 indicates that the instances used in this study had been consistent in measuring the answers of the study respondents. Cronbach's alpha value $>0,7$ indicated good reliability of the research instruments.

\subsubsection{Descriptive statistics analysis results}

\subsubsection{Location variables}

Location could be a factor of consideration for consumers in choosing a suitable residence for themselves. The Global Appraisal Institute carried out the three "L" placements of location as the accessibility of the premises for the user, the location as the mobility of the user, and the location as the availability of the facility essential to the user as a determinant of the fair value of a residence.

\subsubsection{Accessibility constructs}

Location factor of accessibility relates to how easily the location is reachable by the owner or owner-related. The higher the accessibility level of a place was, usually the higher the value of the location got. The results of descriptive statistics for accessibility construct are summarized in Table 3.

Table 3. Accessibility construct descriptive statistics

Source: SmartPLS Result (2018)

\begin{tabular}{|c|c|c|c|c|c|c|}
\hline \multirow[b]{2}{*}{ Statement } & \multicolumn{5}{|c|}{ Response } & \multirow[b]{2}{*}{ ֻั } \\
\hline & 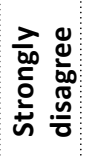 & 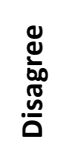 & 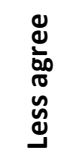 & 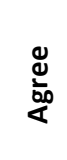 & 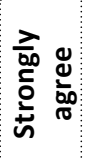 & \\
\hline $\begin{array}{l}\text { The housing is close } \\
\text { to the highway }\end{array}$ & $0 \%$ & $0 \%$ & $8 \%$ & $42 \%$ & $50 \%$ & 4.42 \\
\hline $\begin{array}{l}\text { This housing is easy } \\
\text { to reach by car }\end{array}$ & $0 \%$ & $0 \%$ & $18 \%$ & $28 \%$ & $54 \%$ & 4.35 \\
\hline $\begin{array}{l}\text { The housing is close } \\
\text { to the trajectory } \\
\text { of public transport }\end{array}$ & $0 \%$ & $0 \%$ & $16 \%$ & $65 \%$ & $19 \%$ & 4.03 \\
\hline \multicolumn{6}{|l|}{ Accessibility score } & 4.27 \\
\hline
\end{tabular}


Table 3 indicates that the majority of respondents (18\%) still stated that their residential location was a bit difficult to reach by car. As many as $16 \%$ of respondents also considered that the location of housing was still less close to public transport trajectory.

\subsubsection{Mobility construct}

The results of the descriptive statistics on mobility construct are summarized in Table 4 .

Table 4. Mobility construct descriptive statistics

\begin{tabular}{|c|c|c|c|c|c|c|}
\hline \multirow[b]{3}{*}{ Statement } & \multicolumn{6}{|c|}{ Source: SmartPLS Result (2018 } \\
\hline & \multicolumn{5}{|c|}{ Response } & \multirow[b]{2}{*}{ 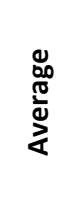 } \\
\hline & 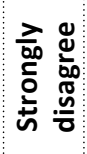 & $\begin{array}{l}\text { d } \\
\frac{1}{20} \\
\frac{\omega}{0} \\
\frac{\omega}{0}\end{array}$ & 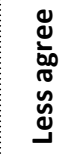 & 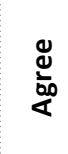 & $\begin{array}{ll}\frac{\lambda}{60} & d \\
\frac{1}{0} & \frac{1}{20} \\
\vdots & 0\end{array}$ & \\
\hline $\begin{array}{l}\text { This housing is close } \\
\text { to where I work }\end{array}$ & $0 \%$ & $8 \%$ & $58 \%$ & $29 \%$ & $5 \%$ & 3.31 \\
\hline $\begin{array}{l}\text { This housing is close } \\
\text { to my child's school } \\
\text { location }\end{array}$ & $0 \%$ & $0 \%$ & $6 \%$ & $19 \%$ & $75 \%$ & 4.69 \\
\hline $\begin{array}{l}\text { The housing is close to } \\
\text { the grocery store }\end{array}$ & $0 \%$ & $0 \%$ & $8 \%$ & $68 \%$ & $24 \%$ & 4.17 \\
\hline \multicolumn{6}{|l|}{ Mobility score } & 4.06 \\
\hline
\end{tabular}

Table 4 indicates that in general the housing owned has an average score of 4.06 . This indicated that proximity to the work site was more ruled out in the choice of shelter when compared to the location of schoolchildren and the market for shopping for daily needs.

\subsubsection{Facility construct}

The evaluation results of descriptive statistics to facility construct are summarized in Table 5 .

Table 5. Facility construct descriptive statistics

Source: SmartPLS Result (2018).

\begin{tabular}{|c|c|c|c|c|c|c|}
\hline \multirow[b]{2}{*}{ Statement } & \multicolumn{5}{|c|}{ Response } & \multirow[b]{2}{*}{ 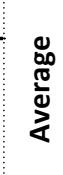 } \\
\hline & 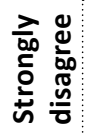 & $\begin{array}{l}\stackrel{ \pm}{d} \\
\frac{1}{00} \\
\stackrel{0}{0} \\
\stackrel{0}{0}\end{array}$ & 岃 & 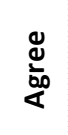 & 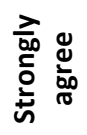 & \\
\hline $\begin{array}{l}\text { This housing is close } \\
\text { to hospital }\end{array}$ & $0 \%$ & $13 \%$ & $27 \%$ & $46 \%$ & $15 \%$ & 3.63 \\
\hline $\begin{array}{l}\text { The housing is close } \\
\text { to shopping center }\end{array}$ & $0 \%$ & $0 \%$ & $6 \%$ & $68 \%$ & $27 \%$ & 4.21 \\
\hline $\begin{array}{l}\text { This housing has a } \\
\text { beautiful view }\end{array}$ & $0 \%$ & $8 \%$ & $18 \%$ & $48 \%$ & $25 \%$ & 3.90 \\
\hline $\begin{array}{l}\text { The housing is close } \\
\text { to the city center }\end{array}$ & $0 \%$ & $0 \%$ & $17 \%$ & $49 \%$ & $34 \%$ & 4.18 \\
\hline \multicolumn{6}{|l|}{ Facility score } & 3.98 \\
\hline
\end{tabular}

Table 5 provides information that in general the facility was already perceived quite well by the respondents with an average score of 3.98. In general, the housing projects had been perceived as close to both hospitals, shopping centers, parks or beautiful scenery, as well as downtown.

\subsubsection{Environment construct}

The environment construct evaluation is summarized in Table 6.

Table 6. Environment construct descriptive statistics

Source: SmartPLS Result (2018)

\begin{tabular}{|c|c|c|c|c|c|c|}
\hline \multirow[b]{2}{*}{ Statement } & \multicolumn{5}{|c|}{ Response } & \multirow[b]{2}{*}{ 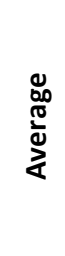 } \\
\hline & 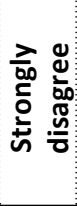 & 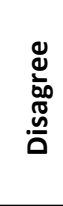 & 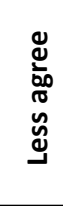 & 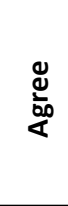 & 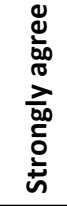 & \\
\hline $\begin{array}{l}\text { The area around this } \\
\text { housing is free from } \\
\text { criminal acts }\end{array}$ & $0 \%$ & $0 \%$ & $0 \%$ & $42 \%$ & $58 \%$ & 4.58 \\
\hline $\begin{array}{l}\text { This housing is free from } \\
\text { noise }\end{array}$ & $0 \%$ & $0 \%$ & $0 \%$ & $34 \%$ & $66 \%$ & 4.66 \\
\hline $\begin{array}{l}\text { This housing has a well- } \\
\text { established impression }\end{array}$ & $0 \%$ & $0 \%$ & $8 \%$ & $71 \%$ & $21 \%$ & 4.13 \\
\hline $\begin{array}{l}\text { This housing area is free } \\
\text { from floods }\end{array}$ & $0 \%$ & $0 \%$ & $7 \%$ & $73 \%$ & $21 \%$ & 4.14 \\
\hline \multicolumn{6}{|l|}{ Environment score } & 4.38 \\
\hline
\end{tabular}

Generally, Table 6 indicates that environmental construct in location variable was already in a very good perception.

\subsubsection{Economic value variable of housing}

The economic value of a product was based on the DUST function, which was a combination of desire, utility, scarcity, and transferable. The classic example that was often given in the learning of Economic Value was why the Diamond was much more expensive than water which was the basic human's need.

\subsubsection{Desire construct}

Descriptive statistical evaluation of desire construct is summarized in Table 7. 
Table 7. Desire construct descriptive statistics

\begin{tabular}{|c|c|c|c|c|c|c|}
\hline \multirow[b]{2}{*}{ Statement } & \multicolumn{5}{|c|}{ Response } & \multirow[b]{2}{*}{ 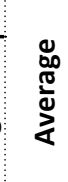 } \\
\hline & 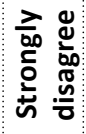 & 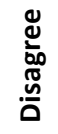 & 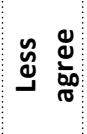 & $\frac{\searrow}{0}$ & 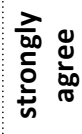 & \\
\hline $\begin{array}{l}\text { This house is my dream } \\
\text { house }\end{array}$ & $0 \%$ & $0 \%$ & $5 \%$ & $75 \%$ & $21 \%$ & 4.16 \\
\hline $\begin{array}{l}\text { This house has an } \\
\text { ornament with } \\
\text { aesthetic value that I } \\
\text { think is good }\end{array}$ & $0 \%$ & $0 \%$ & $18 \%$ & $31 \%$ & $60 \%$ & 4.78 \\
\hline $\begin{array}{l}\text { I have searched for } \\
\text { alternative house } \\
\text { options before buying } \\
\text { a house in this housing }\end{array}$ & $0 \%$ & $0 \%$ & $21 \%$ & $43 \%$ & $45 \%$ & 4.61 \\
\hline \multicolumn{6}{|l|}{ Desire score } & 4.52 \\
\hline
\end{tabular}

Table 7 indicates that housing owned or occupied by the respondent was housing that was really interesting with the average value of the desire construct of 4.52 .

\subsubsection{Utility construct}

Descriptive statistical evaluation of utility construct is summarized in Table 8.

Table 8. Utility construct descriptive statistics

\begin{tabular}{|c|c|c|c|c|c|c|}
\hline & & & Sources & s: Smar & DS Resul & t (201 \\
\hline \multirow[b]{2}{*}{ Statement } & \multicolumn{5}{|c|}{ Response } & \multirow[b]{2}{*}{ 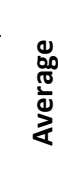 } \\
\hline & 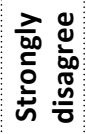 & 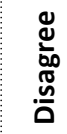 & 凹 & 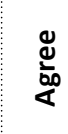 & 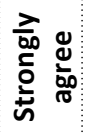 & \\
\hline $\begin{array}{l}\text { This house provides } \\
\text { everything I need as } \\
\text { a place to stay }\end{array}$ & $0 \%$ & $0 \%$ & $0 \%$ & $40 \%$ & $60 \%$ & 4.60 \\
\hline $\begin{array}{l}\text { This housing is free } \\
\text { from bad things that } \\
\text { I worry about }\end{array}$ & $0 \%$ & $0 \%$ & $0 \%$ & $28 \%$ & $72 \%$ & 4.72 \\
\hline $\begin{array}{l}\text { This house provides } \\
\text { optimal comfort for } \\
\text { my family }\end{array}$ & $0 \%$ & $0 \%$ & $0 \%$ & $23 \%$ & $77 \%$ & 4.77 \\
\hline \multicolumn{6}{|l|}{ Utility score } & 4.69 \\
\hline
\end{tabular}

Table 8 indicates that the utility of housing owned by the respondent was optimal. Occupied house was a house that was able to provide all the housing needs of its owner.

\subsubsection{Scarcity construct}

Descriptive statistics of scarcity construct is summarized in Table 9.
Table 9. Scarcity construct descriptive statistics

Sources: SmartPLS Result (2018)

\begin{tabular}{|c|c|c|c|c|c|c|}
\hline \multirow[b]{2}{*}{ Statement } & \multicolumn{5}{|c|}{ Response } & \multirow[b]{2}{*}{ 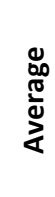 } \\
\hline & 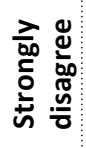 & 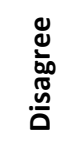 & 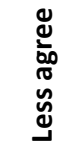 & 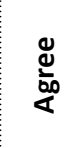 & 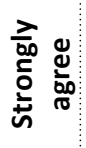 & \\
\hline $\begin{array}{l}\text { All the housing in this } \\
\text { place in my opinion is } \\
\text { fully charged }\end{array}$ & $0 \%$ & $0 \%$ & $10 \%$ & $58 \%$ & $32 \%$ & 4.22 \\
\hline $\begin{array}{l}\text { I find it difficult to } \\
\text { find another housing } \\
\text { comparable to this } \\
\text { one }\end{array}$ & $0 \%$ & $0 \%$ & $8 \%$ & $77 \%$ & $15 \%$ & 4.07 \\
\hline $\begin{array}{l}\text { I feel looking for a } \\
\text { new place to stay is } \\
\text { difficult }\end{array}$ & $0 \%$ & $0 \%$ & $19 \%$ & $63 \%$ & $18 \%$ & 3.98 \\
\hline \multicolumn{6}{|l|}{ Scarcity score } & 4.09 \\
\hline
\end{tabular}

Table 9 indicates that the presence of similar housing was quite rare with an average value of 4.09. In general, similar housing was already difficult to find and generally was full.

\subsubsection{Transferable constructs}

Descriptive statistical analysis of transferable aspects is summarized in Table 10.

Table 10. Transferable construct descriptive statistics

Sources: SmartPLS Result (2018).

\begin{tabular}{|c|c|c|c|c|c|c|}
\hline \multirow[b]{2}{*}{ Statement } & \multicolumn{5}{|c|}{ Response } & \multirow[b]{2}{*}{ 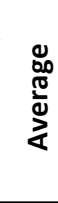 } \\
\hline & 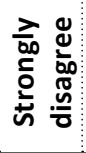 & 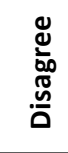 & 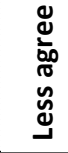 & 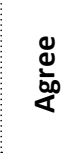 & 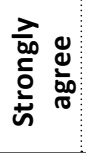 & \\
\hline $\begin{array}{l}\text { The affairs of } \\
\text { the housing } \\
\text { correspondence are } \\
\text { easy to complete }\end{array}$ & $0 \%$ & $0 \%$ & $0 \%$ & $58 \%$ & $42 \%$ & 4.42 \\
\hline $\begin{array}{l}\text { This housing has a } \\
\text { clear legal status }\end{array}$ & $0 \%$ & $0 \%$ & $0 \%$ & $65 \%$ & $35 \%$ & 4.35 \\
\hline $\begin{array}{l}\text { I see that this housing } \\
\text { has a high potential } \\
\text { for resale }\end{array}$ & $0 \%$ & $0 \%$ & $7 \%$ & $69 \%$ & $24 \%$ & 4.18 \\
\hline \multicolumn{6}{|l|}{ Transferable score } & 4.31 \\
\hline
\end{tabular}

Table 10 summarizes that in general the respondents occupied housing which was easily transferable. In addition, respondents perceived that the resale price of housing was also promising. Nevertheless, as many as $7 \%$ of the respondents did not agree with it. 


\subsubsection{Customer perceived value variable}

The essence of the value was the difference between benefits gained and the sacrifice that should be done by someone.

\subsubsection{Product-related value}

The perceived value of the product was related to the user's functional evaluation of the product itself. Descriptive statistical evaluation for the value perception dimension is summarized in Table 11.

Table 11. Product construct descriptive statistics

Source: SmartPLS Result (2018)

\begin{tabular}{|c|c|c|c|c|c|c|}
\hline \multirow[b]{2}{*}{ Statement } & \multicolumn{5}{|c|}{ Response } & \multirow[b]{2}{*}{ 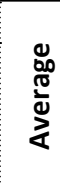 } \\
\hline & 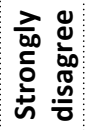 & 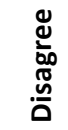 & 气̆ & 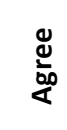 & $\begin{array}{ll}\frac{\lambda}{00} & d \\
\frac{c}{0} & \frac{1}{20} \\
\frac{1}{n} & \sigma\end{array}$ & \\
\hline $\begin{array}{l}\text { I feel this house is } \\
\text { suitable as a family } \\
\text { residence }\end{array}$ & $0 \%$ & $0 \%$ & $4 \%$ & $61 \%$ & $35 \%$ & 4.31 \\
\hline $\begin{array}{l}\text { I feel the price of } \\
\text { this house is in } \\
\text { accordance with } \\
\text { what I expect }\end{array}$ & $0 \%$ & $0 \%$ & $5 \%$ & $60 \%$ & $35 \%$ & 4.30 \\
\hline $\begin{array}{l}\text { I feel this home is } \\
\text { comfortable as my } \\
\text { place to rest }\end{array}$ & $0 \%$ & $0 \%$ & $10 \%$ & $59 \%$ & $31 \%$ & 4.21 \\
\hline $\begin{array}{l}\text { I feel generally } \\
\text { satisfied with the } \\
\text { house I bought }\end{array}$ & $0 \%$ & $0 \%$ & $0 \%$ & $59 \%$ & $41 \%$ & 4.41 \\
\hline \multicolumn{6}{|l|}{ Product score } & 4.31 \\
\hline
\end{tabular}

Table 11 indicates that the perception of consumers in terms of the value of its existing home was in excellent condition with the average value of 4.27.

\subsubsection{Social-related value}

Descriptive statistical evaluation dimension of perceived value from a social perspective on houses that had been purchased is summarized in Table 12 .

Table 12. Social construct descriptive statistics

Source: SmartPLS Result (2018).

\begin{tabular}{|c|c|c|c|c|c|c|}
\hline \multirow[b]{2}{*}{ Statement } & \multicolumn{5}{|c|}{ Response } & \multirow[b]{2}{*}{ 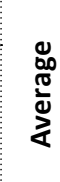 } \\
\hline & 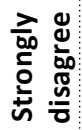 & 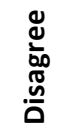 & 气ू & $\underset{\frac{d}{\alpha 0}}{\frac{d}{\alpha}}$ & 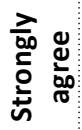 & \\
\hline $\begin{array}{l}\text { I feel living in this } \\
\text { housing makes me } \\
\text { more appreciated by } \\
\text { the family }\end{array}$ & $0 \%$ & $13 \%$ & $33 \%$ & $36 \%$ & $18 \%$ & 3.60 \\
\hline
\end{tabular}

\begin{tabular}{|c|c|c|c|c|c|c|}
\hline \multirow[b]{2}{*}{ Statement } & \multicolumn{5}{|c|}{ Response } & \multirow[b]{2}{*}{ ญ } \\
\hline & 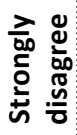 & 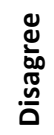 & 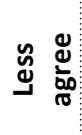 & 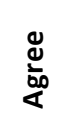 & 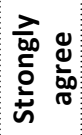 & \\
\hline $\begin{array}{l}\text { I feel that living in this } \\
\text { housing makes me } \\
\text { more appreciated by } \\
\text { co-workers }\end{array}$ & $0 \%$ & $1 \%$ & $5 \%$ & $75 \%$ & $19 \%$ & 4.13 \\
\hline $\begin{array}{l}\text { Relatives like to praise } \\
\text { me for the ownership } \\
\text { of this house }\end{array}$ & $0 \%$ & $0 \%$ & $13 \%$ & $54 \%$ & $33 \%$ & 4.21 \\
\hline $\begin{array}{l}\text { A colleague who visits } \\
\text { give me compliments } \\
\text { for the house I have }\end{array}$ & $0 \%$ & $2 \%$ & $7 \%$ & $57 \%$ & $35 \%$ & 4.25 \\
\hline \multicolumn{6}{|l|}{ Social mean } & 4.05 \\
\hline
\end{tabular}

Table 12 indicates that the average perception of the value of changes in social values that the respondent felt quite well is with the average value of 4.05. The fewest social change happened to the respondent was a change of social status in the eyes of the family or relatives with an average score of 3.60 , which is in the range under a proper category.

\subsubsection{Personal-related value}

Descriptive statistical evaluation for the dimension of perceived value from a personal standpoint on a house that had been bought is summarized in Table 13.

Table 13. Personal construct descriptive statistics

Source: SmartPLS Result (2018)

Response

\begin{tabular}{|c|c|c|c|c|c|}
\hline Statement & 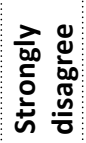 & $\begin{array}{l}\stackrel{ \pm}{0} \\
\frac{1}{00} \\
\frac{.0}{0} \\
\frac{0}{0}\end{array}$ & 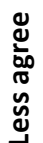 & 这 & 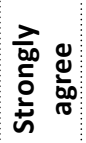 \\
\hline
\end{tabular}

\begin{tabular}{|c|c|c|c|c|c|c|}
\hline $\begin{array}{l}\text { Staying in this housing } \\
\text { makes me feel more } \\
\text { classy }\end{array}$ & $0 \%$ & $19 \%$ & $57 \%$ & $20 \%$ & $4 \%$ & 3.09 \\
\hline $\begin{array}{l}\text { People like to praise } \\
\text { my successes, one of } \\
\text { them through living in } \\
\text { this housing }\end{array}$ & $0 \%$ & $0 \%$ & $12 \%$ & $67 \%$ & $22 \%$ & 4.10 \\
\hline $\begin{array}{l}\text { This housing makes } \\
\text { me able to keep my } \\
\text { family better }\end{array}$ & $0 \%$ & $0 \%$ & $0 \%$ & $54 \%$ & $46 \%$ & 4.46 \\
\hline $\begin{array}{l}\text { This house helps } \\
\text { me prepare for the } \\
\text { children in the future }\end{array}$ & $0 \%$ & $0 \%$ & $0 \%$ & $57 \%$ & $43 \%$ & 4.43 \\
\hline \multicolumn{6}{|l|}{ Personal score } & 4.02 \\
\hline
\end{tabular}

Table 13 indicates that respondents had a quite strong personal goal in choosing the housing. The average score of the lowest in the functions 
of personal perception of home ownership was a matter of life more classy with an average score of 3.09 .

\subsubsection{Evaluation model of customer perceived value housing}

\subsection{Validity and model}

Model suitability test on partial least squares was done by evaluating external model using the internal consistency reliability, convergent validity, and discriminant validity. Internal consistency was evaluated using a composite value of reliability in the construct (Bagozzi \& Yi, 1998). Convergent validity was evaluated by using the value of Average Variance Extracted (Hair et al., 2011). Validity testing for reflective indicators in SmartPLS uses a correlation between item scores and construct scores. Measurements with reflective indicators indicate a change in an indicator in a construct if other indicators of the same construct change (or are removed from the model). Reflective indicators are suitable for measuring perceptions so that this study uses reflective indicators. An indicator is declared valid if it has the highest loading factor to the intended construct rather than loading factors to other constructs (see Figure 1).
Figure 1 indicates that all the indicators of research were appropriate in describing each variable construct in the study. The limit value used in this study was 0.6 . All the indicators had a loading factor $>0,6$ which indicated that the indicator was explaining the model shown in Table 14 and Table 15.

Table 14. Research model validity and reliability

Source: SmartPLS Result (2018)

\begin{tabular}{l|c:c}
\hline \multicolumn{1}{c}{ Variable } & $\begin{array}{c}\text { Composite } \\
\text { reliability }\end{array}$ & $\begin{array}{c}\text { Average variance } \\
\text { extracted }\end{array}$ \\
\hline Customer perceived value & 0932 & 0820 \\
\hline Economic value & 0922 & 0.746 \\
\hdashline Locational factor & 0.840 & 0573 \\
\hline
\end{tabular}

Table 15. Fornell-Larcker criterion

Source: SmartPLS Result (2018)

\begin{tabular}{l|c|c|c}
\hline \multicolumn{1}{c|}{ Variable } & $\begin{array}{c}\text { Customer } \\
\text { perceived value }\end{array}$ & $\begin{array}{c}\text { Economic } \\
\text { value }\end{array}$ & $\begin{array}{c}\text { Location } \\
\text { factor }\end{array}$ \\
\hline $\begin{array}{l}\text { Customer } \\
\text { perceived value }\end{array}$ & 0906 & - & - \\
\hline Economic value & 0259 & 0864 & - \\
\hline Location factor & 0.139 & 0739 & 0.757 \\
\hline
\end{tabular}

Table 14 and Table 15 conclude that the model proposed in this study met the criteria of reliability and validity in the PLS model conformity test.

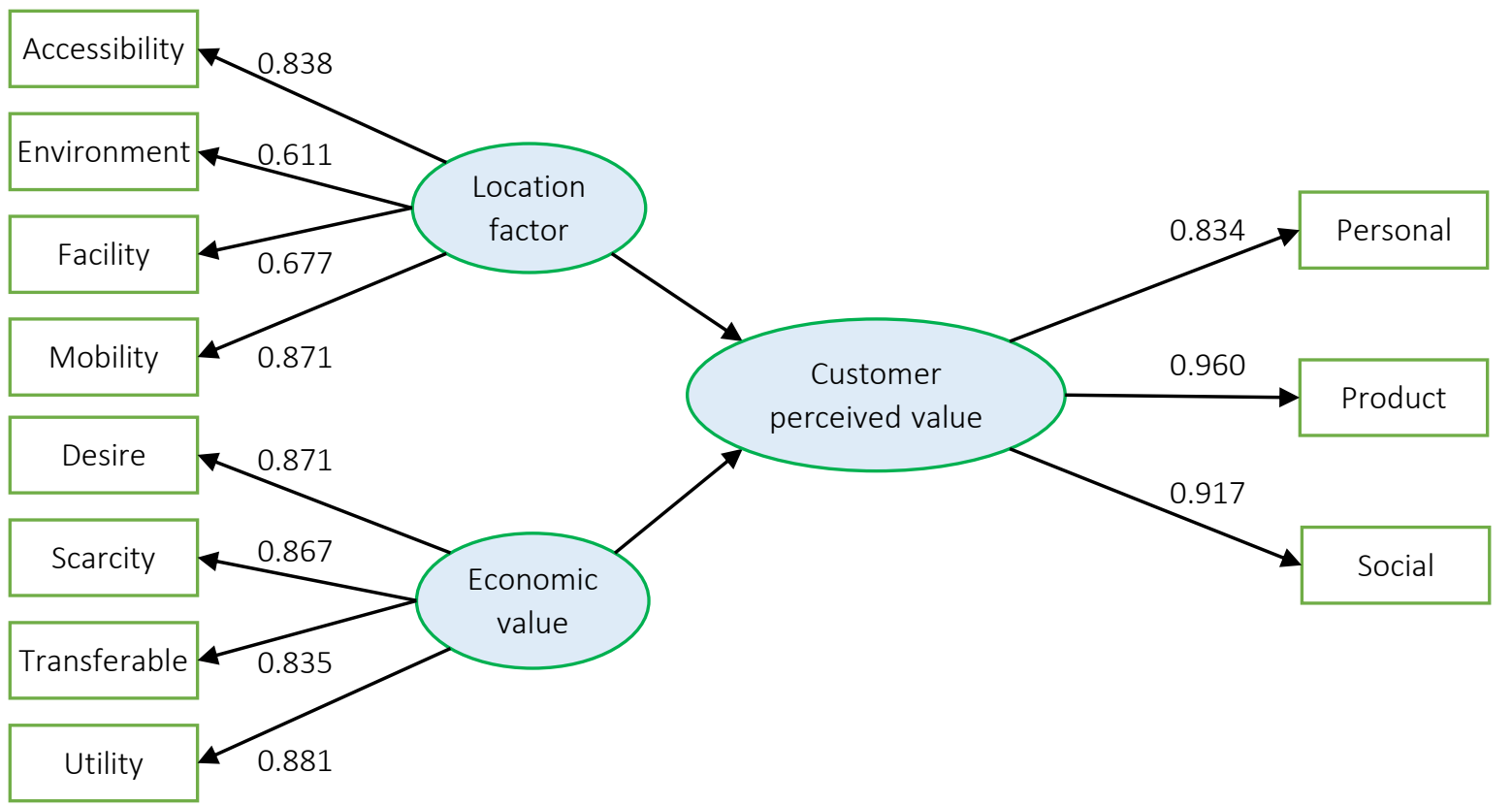

Figure 1. Outer loading research model 
Table 16. Hypotheses testing

Source: SmartPLS Result (2018).

\begin{tabular}{l|c|c}
\hline \multicolumn{1}{c|}{ Hypothesis } & $\begin{array}{c}\text { Path } \\
\text { coefficient }\end{array}$ & Significance \\
\hline $\begin{array}{l}\text { Location factor of housing positively and significantly affects consumer's } \\
\text { perceptions }\end{array}$ & 0.114 & Decision \\
\hline $\begin{array}{l}\text { Economic value factor of housing positively and significantly affects consumer's } \\
\text { perceptions }\end{array}$ & 0.344 & Accept \\
\hline
\end{tabular}

\subsection{Evaluation model}

Evaluation model is summarized in Figure 2. Figure 2 provides that in terms of location, accessibility and mobility overall played an important role for the location factor.

\subsubsection{Hypotheses testing}

The results of the bootstrap evaluation is summa- rized in Table 16.

Table 16 indicates that both research hypotheses were accepted. There was a positive and significant effect of the location factor on consumer's perceptions of the value of housing $(\operatorname{sig}=0.042<0.05)$. Furthermore, the economic value factor of housing had a positive and significant influence on consumer's perceptions of the value of housing ( $\operatorname{sig}=0.000<0.05$ ) .

\section{CONCLUSION}

The economic value of this research acted as a dominant variable in driving consumer value perception. The developers should ensure that the main function of the home is a comfortable refuge from the weather. Customer perceived value is predominantly explained by the ability of the product to meet consumers' expectations. Consumers will highly evaluate the economic value of the housing units offered by the residential. The price offered will be very sensitive to the perceived value of the product. From the social perspective of the housing offered, it should be able to give a classy impression that can increase consumers' interest. The study showed that both locational and economic values have a positive and significant effect on the customer perceived value. A better locational aspect would increase the perceived value. It is more likely for a customer to purchase a house within strategic location. It is important to select a location with good accessibility and mobility aspect. Economic value acted as a dominant aspect to create customer perceived value (Demirgunes, 2015; Heskett, 2009). The perceived value will be improved as customer had a better perceived house economic value. Determining the location and how to manage the site and explain the benefits of the location of a housing to prospective customers is an important factor in building value in the minds of consumers. Aspects most preferred by consumers are the mobility on routine household expenditures and the child mobility. The location chosen and built should be close to the highway and able to be easily accessed by car. The economic value of the housing is the dominant factor in building the value in consumer's mind. It should be noted that the utility of housing offered must be aligned to or be greater than consumers' expectations. Consumers pay a huge attention to the product issue, namely the housing unit itself. The practical implication of this research is the need for the provision of funds from the government in the form of the procurement of toll road infrastructure and the construction of public facilities such as water and gas electricity that support housing. Social implications in the form of characteristics of home buyers and income factors can be influential in this study.

\section{ACKNOWLEDGMENT}

The authors would like to thank the Universitas Sumatera Utara, which fully funded this research. This research was funded by PNBP Talenta USU 2017 under the Basic Research scheme. 


\section{REFERENCES}

1. Appraisal Institute. (2008). The Appraisal of Real Estate (13th ed.). Chicago: Appraisal Institute.

2. Ashraf, S., Ilyas, R., Imtiaz, M., \& Ahmad, S. (2018). Impact of Service Quality, Corporate Image and Perceived Value on Brand Loyalty with Presence and Absence of Customer Satisfaction. International Journal of Academic Research in Business and Social Sciences, 8(2), 452-474. https://doi. org/10.6007/IJARBSS/v8-i2/3885

3. Bakar, N. A., Aminallah, A. A., Rahim, S. S., Zam, N. M., Rahman, S. A., \& Veerayangkur, V. (2018). Examining the relationship of website security, online perceived value and online purchase intention. Journal of Fundamental and Applied Sciences, 10(6S), 11761191. Retrieved from http://jfas. info/psjfas/index.php/jfas/article/ view/4337

4. Betts, R. M. (2012). Basic Real Estate Appraisal: Principles and Procedures. USA: Cengage Learning.

5. Birinci, H., Berezina, K., \& Cobanoglu, C. (2018). Comparing customer perceptions of hotel and peer-to-peer accommodation advantages and disadvantages. International Journal of Contemporary Hospitality Management, 30(2), 11901210. https://doi.org/10.1108/ IJCHM-09-2016-0506

6. Carlson, J., Rahman, M., Voola, R., \& De Vries, N. (2018). Customer engagement behaviours in social media: capturing innovation opportunities. Journal of Services Marketing, 32(1), 83-94. https:// doi.org/10.1108/JSM-02-20170059

7. Chekalina, T., Fuchs, M., \& Lexhagen, M. (2018). Customerbased destination brand equity modeling: The role of destination resources, value for money. Journal of Travel Research, 57(1), 31-51. https://doi.org/10.1177\%2F0047287516680774

8. Creusen, M. E. H., \& Schoormans, J. P. L. (2005).
The different roles of product appearance in consumer choice. Journal of Product Innovation Management, 22(1), 63-81. https://doi.org/10.1111/j.07376782.2005.00103.x

9. Dedeoglu, B. B., Bilgihan, A., Ye, B. H., Buonincontri, P., \& Okumus, F. (2018). The impact of service scape on hedonic value and behavioral intentions. International Journal of Hospitality Management, 72, 10-20. https://doi.org/10.1016/j. ijhm.2017.12.007

10. Demirgunes, B. K. (2015). Relative importance of perceived value, satisfaction, and perceived risk on willingness to pay more. International Review of Management and Marketing, 5(4), 211-220. Retrieved from http:// www.econjournals.com/index. php/irmm/article/view/1465

11. Erkmen, E., \& Hancer, M. (2018). Creating Value for Restaurant Customer: The Role of Other Customers in Dining Experience. Tourist Behavior (pp. 157-171). Springer, Cham.

12. Gallarza, M. G., \& Gil, I. (2006). Value dimensions, perceived value, satisfaction and loyalty: An investigation of university students travel behavior. Tourism Management, 27(3), 437-452. https://doi.org/10.1016/j.tourman.2004.12.002

13. Gong, T., \& Yi, Y. (2018). The effect of service quality on customer satisfaction, loyalty, and happiness in five Asian countries. Psychology \& Marketing, 35(6), 427-442. https://doi.org/10.1002/ mar.21096

14. Gordon, R., Dibb, S., Magee, C., Cooper, P., \& Waitt, G. (2018). Empirically testing the concept of value-in-behavior and its relevance for social marketing. Journal of Business Research, 82, 56-67. https://doi.org/10.1016/j. jbusres.2017.08.035

15. Hair, J. F., Ringle, C. M., \& Sarstedt, M. (2011). PLS-SEM: Indeed a Silver Bullet. Journal of Marketing Theory and Practice, 19(1), 139-152. https:// doi.org/10.2753/MTP10696679190202

16. Harris, P., Rettie, R., \& Kwan, C. C. (2005). Adoption and usage of m-commerce: A crosscultural comparison of Hong Kong and the United Kingdom. Journal of Electronic Commerce Research, 6(3), 210-224. Retrieved from https://eprints.kingston. ac.uk/2080/

17. Heskett, J. (2009). Creating economic value by design. International Journal of Design, 3(1), 88-96. Retrieved from http:// www.ijdesign.org/index.php/IJDesign/article/view/477/243

18. Huber, F., Herrmann, A., \& Morgan, R. E. (2001). Gaining competitive advantage through customer value oriented management. Journal of Consumer Marketing, 18(1), 41-53. http://dx.doi. org/10.1108/07363760110365796

19. Huderek, S. Glapska, \& Trojanek, R. (2013). The impact of aircraft noise on house prices. International Journal of Academic Research, 5(3), 397-408.

20. Hwang, E., Baloglu, S., \& Tanford, S. (2019). Building loyalty through reward programs: The influence of perceptions of fairness and brand attachment. International Journal of Hospitality Management, 76, 19-28. https://doi.org/10.1016/j. ijhm.2018.03.009

21. Khalifa, A. S. (2004). Customer value: A review of recent literature and an integrative configuration. Management Decision, 42(5), 645-666. https://doi. org/10.1108/00251740410538497

22. Kolbe, J., Schulz, R., Wersing, M., \& Werwatz, A. (2012). Extracting location value from house prices (Discussion Paper). Berlin: Deutsches Institut für Wirtschaftsforschung. Retrieved from https://ideas.repec.org/p/ diw/diwwpp/dp1216.html 
23. Leckie, C., Nyadzayo, M. W., \& Johnson, L. W. (2018). Promoting brand engagement behaviors and loyalty through perceived service value and innovativeness. Journal of Services Marketing, 32(1), 70-82. https://doi.org/10.1108/JSM-012017-0035

24. Lee, S., \& Phau, I. (2018). Young tourists perceptions of authenticity, perceived value and satisfaction. Young Consumers, 19(1), 70-86. https://doi. org/10.1108/YC-07-2017-00714

25. Lima, L. P., Miron, L., Leite, F., \& Formoso, C. (2009). Perceived value in social housing projects. Proceedings of IGLC17: 17th Annual Conference of the International Group for Lean Construction. Retrieved from https://researchers.dellmed.utexas. edu/en/publications/perceivedvalue-in-social-housing-projects

26. Lin, J. S. S. (2018). The Moderating Role of Intercultural Service Encounters in the Relationship among Tourist's Destination Image, Perceived Value and Environmentally Responsible Behaviors. American Journal of Tourism Management, 7(1), 1-9. Retrieved from http:// article.sapub.org/10.5923.j.touri sm.20180701.01.html

27. Maslow, A. H. (1943). A theory of human motivation. Psychological Review, 50, 370-396. Retrieved from https://psychclassics.yorku. $\mathrm{ca} /$ Maslow/motivation.htm

28. Ringle, C. M., Wende, S., \& Becker, J. M. (2018). SmartPLS 3, Boenningstedt: SmartPLS. Retrieved from http://www.smartpls.com (accessed on August 12, 2018).

29. Sanchez-Fernandez, R., \& Iniesta-Bonillo, M. A. (2007). The concept of perceived value: A systematic review of the research. Marketing Theory, 7(4), 427-451. https://doi.org/10.1177\%2F1470593107083165

30. Sekaran, U. (2003). Research Methods for Business: A Skill Building Approach (5th ed.). New Jersey: John Willey \& Son Inc.
31. Siahaan, E. (2015). Concept and Application of Managerial Economics in Business. Medan. USU Press.

32. Siahaan, E. (2017). The Role of Compensation. Polish Journal of Management Studies, 15(1), 181192.

33. Simon, F., \& Tossan, V. (2018). Does brand-consumer social sharing matter? A relational framework of customer engagement to brand-hosted social media. Journal of Business Research, 85, 175-184. https://doi. org/10.1016/j.jbusres.2017.12.050

34. Sirdeshmukh, D., Ahmad, N. B., Khan, M. S., \& Ashill, N. J. (2018). Drivers of user loyalty intention and commitment to a search engine. Journal of Retailing and Consumer Services, 44, 71-81. https://doi.org/10.1016/j.jretconser.2018.06.002

35. Srour, I. M., Kockelman, K. M., \& Dunn, T. P. (2002) Accessibility indices: A connection to residential land prices and location choices. Transportation Research Record, 1805(1), 25-34. https://doi. org/10.3141\%2F1805-04

36. Sweeney. (1994). An Investigation of a Theoretical Model of Consumer Perception of Value (Doctoral Dissertation). School of Management and Marketing, Australia. Curtain University of Technology.

37. Wang, Y. Y., Lin, H. H., Wang, Y. S., Shih, Y. W., \& Wang, S. T. (2018). What drives users intentions to purchase a GPS Navigation. The moderating role of perceived availability of free substitutes. Internet Research, 28(1), 251-274. https://doi.org/10.1108/IntR-112016-0348

38. Wang, Y., Lo, H. P., Chi, R., \& Yang, Y. (2004). An integrated framework for customer value and customer-relationshipmanagement performance. Managing Service Quality, 14(2-3), 169-182.

39. Wojnarwsky, P., Wang, Y., Shah, K., \& Koka, S. (2017). Factors influencing resident choice of Prosthodontic Residency Program.
Journal of Prosthodontics, 26(4), 339-343. https://doi.org/10.1111/ jopr.12599

40. Zemke, D. M. V., Raab, C., \& $\mathrm{Wu}, \mathrm{K}$. (2018). How does hotel design contribute to property performance? International Journal of Contemporary Hospitality Management, 30(2), 919-938. https://doi.org/10.1108/ IJCHM-06-2016-0330

41. Zhang, Y., Bian, X., Cao, A., \& Yu, Z. (2018). The Influence of Self-Concept on Perceived Value in Apparel Brand Adoption Behavior-Based on Research Data. Asian Social Science, 14(7), 47-58.

42. Źróbek, S.; Trojanek, M.; ŹrobekSokolnik, A.; \& Trojanek, R. (2015). The influence of environmental factors on property buyers' choice of residential location in Poland. Journal of International Studes, 8(1), 164-174. Retrieved from http://yadda.icm.edu.pl/yadda/ element/bwmeta1.element.ekonelement-000171401235 